\title{
The Importance of Old, Traditionally Managed Orchards for Breeding Birds in the Agricultural Landscape
}

\author{
Slawomir Chmielewski* \\ Institute of Technology and Life Sciences, Falenty, Raszyn, Poland
}

Received: 4 May 2018

Accepted: 3 September 2018

\begin{abstract}
The purpose of this study was to characterise the breeding birds of an old, extensively managed apple orchard and its influence on the biodiversity of the agricultural landscape in central Poland. What distinguishes old orchards from other habitats is the very high density of birds and the simplified species composition. The assemblages of birds are governed by an orchard's age and the diversity of the habitats surrounding it. The non-use of chemicals in a traditional orchard was not found to limit the composition of bird species. Ten species nested in the orchard. The bird species and brood success were determined for 68 completed nests.
\end{abstract}

Keywords: farmland habitat, agricultural practices, pesticides, orchards

\section{Introduction}

Old, traditionally (i.e., extensively) managed orchards consist mainly of widely spaced, fast- and tallgrowing trees with broad crowns. Trees in commercial orchards are low and grow more slowly, but enter the fruiting phase sooner, and are narrowly spaced. Another distinguishing feature is the selection of fruit tree varieties and intensive chemical protection $[1,2]$. Since traditional orchards are no longer planted, they are disappearing from the landscape [3, 4], and their surviving remnants are being grubbed up and replaced with new varieties of trees and commercial orchards. Old varieties of apples are not attractive for modern, large-scale trading and have therefore disappeared from the market.

*e-mail: sch6@wp.pl
Traditional orchards are considered to be sanctuaries of biodiversity [3, 5]. In the U.K., such orchards have been treated as protected priority habitats since 2007 [6]. Few if any plant protection products are used in them, they have a lush undergrowth, and bushes like gooseberries or currants grow among the fruit trees. The tree crowns are patulous, the trunks themselves are tall (mostly 1.5-1.8 $\mathrm{m}$ high), and the trees reach an overall height of 5-6 m. The different forms of management in these types of orchards should therefore have an impact on the species composition and numbers of birds.

The rapid decline in traditionally managed orchards has led to highly desirable, detailed research aimed at assessing the part they play in the formation of bird assemblages, because the role and function of such habitats is poorly understood [5, 7-12]. The area of orchards (approx. 1.5 thousand $\mathrm{km}^{2}$ ) around the towns of Grójec and Warka (central Poland), often referred to as "the largest orchard in Europe," is suitable for 
this purpose. This study aimed to assess whether the extensive management of an old, traditional orchard, surrounded by commercial orchards, has a significant influence on the birds breeding in an agricultural landscape.

\section{Materials and Methods}

Based on a prior analysis of fruit-growing plantations around Grójec and Warka, a homogeneous area of typical traditional orchards was selected for this survey. The research area, in the shape of an elongated rectangle (1 ha), was situated in the province of Mazovia (Mazowsze), district of Grójec, to the west of Mogielnica $\left(51^{\circ} 41^{\prime} 56.0^{\prime \prime} \mathrm{N} 20^{\circ} 40^{\prime} 53.4^{\prime \prime} \mathrm{E}\right)$. It was surrounded by commercial orchards, and various species of bushes grew to the west. This orchard consisted of fast-growing, tall trees. The oldest ones were aged ca 65 years, the youngest ones about 40 years. Ten old varieties of apple trees and one old variety of pear tree were identified in the orchard, the most common apple varieties being Boiken, Jonathan, Landsberger, Malinówka, Szmalcówka and Antonówka (91\% of all the trees). Six of the 192 trees in the study (1 ha) orchard were Bera Hardy Pears. Old trees were 4.4 to $4.8 \mathrm{~m}$ tall and had a maximum crown spread of $8 \mathrm{~m}$. No intensive agrotechnical measures had been applied to the trees in the survey area; only the grass between the rows of trees was mown four times. On 2 July 2013, the grass under the trees was sprayed once with herbicide (Roundup). No other chemicals were used.

The study was performed in 2013. From 29 April to 10 August, 12 inspections of the whole area were carried out, and every 8 days or so, birds' nests were searched for. The positions of the nests were marked on a 1:800-scale map and these nests were subsequently monitored. Broods were considered successful if nestlings had managed to leave their nest between consecutive nest inspections, or if they had left other traces in the nest such as faeces or feather parts. Based on the progress of nest construction, the time of egg incubation or the age of nestlings, the duration of the breeding period was determined for each species. The durations of clutches (incubation and the period for which the nestlings remained in the nest), including the tempo of nest construction for individual species, were taken from monographic studies [13, 14]. Apart from the above, during the search for nests, the presence of birds and their behaviour were noted in accordance with the cartographic method [15]. This method was used as an auxiliary.

Statistical calculations were performed in $\mathrm{R}$ 3.3.2. software. Owing to the unfulfilled assumptions of the $\chi^{2}$ test, Fisher's exact test was used to check the strength of the relationship of whether the blackbird Turdus merula built its nests at the base of a tree crown (type B) more often than other thrushes. Differences in reproductive success between thrush species and chaffinch Fringilla coelebs, depending on nest height, were examined using the Mann-Whitney $U$ test. Nest height was analysed on the assumption that the birds starting a second clutch may not have been the same as those from the first clutch. Student's t-test for independent samples was applied (assumptions regarding the normality of distribution were fulfilled according to the Shapiro-Wilk test; similar size of groups) to song thrush Turdus philomelos and chaffinch, but the Mann-Whitney U test was used for blackbird and fieldfare Turdus pilaris, owing to the different sizes of the groups compared.

\section{Results}

Eighty-two nests, either fully built or started but not finished, were found in the 1 ha survey area from late April until early August. The bird species and brood success were determined for 68 completed nests. Ten species nested in the orchard. Song thrush and blackbird had the largest number of nests (Table 1). The first clutches (fieldfare) were laid in early April and the last ones in early August (serin Serinus serinus). There were six types of nest site: $\mathrm{A}$ - on the lateral branches of a tree crown, B - at the base of a crown, C - in a tree hole, $\mathrm{D}$ - in a recess, $\mathrm{E}$ - in the fork of the main trunk, and $\mathrm{Z}$ - on the ground. Birds most often built their nests on the lateral branches of tree crowns $(\mathrm{A}=76.8 \%)$ and at the base of a crown $(\mathrm{B}=13.0 \%)$ (Table 1$)$. Nests had been started or completed in four of the eight tree holes, and in recesses found suitable for nesting. Blackbird nests exhibited the greatest diversity with regard to site. When the first clutches were being laid, blackbird nests were found at the base of a tree crown more often than the nests of other species (Table 1). There was a statistically significant correlation between the species of bird and the type of nest $(p=0.021)$. As a result, the frequency of type B nests was higher for blackbirds than for fieldfare and song thrush, a strong relationship $(V=0.56)$.

The height of the trees in the orchard determined the vertical distribution of nests; the highest nests were those of serin and chaffinch. Thrushes Turdinae (song thrush, blackbird, fieldfare) and chaffinch built their nests higher up for the second clutch than for the first one (Table 2). The statistical analysis was performed on the assumption that birds starting the second clutch may not have been the same ones as those from the first clutch. Song thrush (assumptions concerning the normality of distribution fulfilled - Shapiro-Wilk test; similar size of groups) built its second clutch nests higher up than for the first one $\left(\mathrm{t}_{9}=-2.48 ; \mathrm{p}=0.035 ; \mathrm{d}=1.5\right.$; the strength of this effect, indicated by Cohen's d factor, was very high). Owing to the different sizes of the groups compared, blackbird yielded a result close to statistical significance ( $\mathrm{U}=4, \mathrm{Z}=-1.73, \mathrm{p}=0.098$ ), which was probably due to the small number of nests compared, especially second clutch ones. If a larger group had been examined, 
the result would have reached the level of statistical significance, which is indicated by the considerable strength of the effect $(\mathrm{r}=0.66)$. As in the case of blackbird, the results for fieldfare were close to statistical significance $(U=3, Z=1.73, p=0.084)$, the strength of the relationship being indicated by the parameter $\mathrm{r}=0.54$. No such relationship was found for chaffinch $\left(\mathrm{t}_{10}=-1.26\right.$, $\mathrm{p}=0.238, \mathrm{~d}=0.73$ ). The breeding success of 69 clutches was determined: the nestlings from 21 clutches fledged (30.4\%). Only 8 out of 35 (22.9\%) first clutches, 9 out of $20(45 \%)$ second clutches, and 4 out of $10(40 \%)$ repeat clutches were successful. The clutches of common linnet Linaria cannabina, yellowhammer Emberiza citrinella, wood pigeon Columba palumbus and blue tit Cyanistes caeruleus were unsuccessful. $50 \%$ of serin clutches were unsuccessful, as were $56 \%$ of song thrush clutches, $87 \%$ of fieldfare clutches and $93 \%$ of blackbird clutches. Chaffinch experienced the smallest losses (33\%). The success rates of first clutches were as follows: chaffinch $-50 \%$, song thrush $-29 \%$, fieldfare $-14 \%$ and blackbird $-0 \%$. Second clutches that ended successfully were as follows: chaffinch $-100 \%$, song thrush $-60 \%$, blackbird $-0 \%$, and fieldfare $-0 \%$. Repeat clutches which were successful: song thrush $50 \%$ and blackbird $-50 \%$ (each had two such clutches), fieldfare $-20 \%$; chaffinch - no repeat clutches found.

Table 1. Number of breeding pairs and times of clutches determined on the basis of the history of nests in an old, traditionally-managed orchard: A - on the lateral branches of a tree crown, B - at the base of a crown, C - in a tree hole, D - in a recess, E - in the fork of the main trunk, $\mathrm{Z}$ - on the ground.

\begin{tabular}{|c|c|c|c|c|c|c|c|c|c|}
\hline \multirow{2}{*}{ Species } & \multirow{2}{*}{$\begin{array}{l}\text { Number of } \\
\text { breeding pairs }\end{array}$} & \multirow{2}{*}{$\begin{array}{c}\text { Hatching } \\
\text { order }\end{array}$} & \multirow{2}{*}{ Breeding period } & \multicolumn{6}{|c|}{ Type of nest site } \\
\hline & & & & $\mathrm{A}$ & B & $\mathrm{C}$ & $\mathrm{D}$ & $\mathrm{E}$ & $\mathrm{Z}$ \\
\hline \multirow{3}{*}{ Turdus philomelos } & 8 & 1 & $10.04-23.05$ & 7 & 1 & & & & \\
\hline & 5 & 2 & $12.06-13.07$ & 5 & & & & & \\
\hline & 3 & Repeat & Mid-May until mid-June & 3 & & & & & \\
\hline \multirow{3}{*}{ Turdus merula } & 8 & 1 & $15.04-20.05$ & 1 & 5 & & 1 & 1 & \\
\hline & 3 & 2 & $5.06-4.07$ & 3 & & & & & \\
\hline & 2 & Repeat & Late-May - mid-June & 2 & & & & & \\
\hline \multirow{4}{*}{ Turdus pilaris } & 6 & 1 & $9.04-23.05$ & 5 & 2 & & & & \\
\hline & 3 & 2 & Throughout June & 3 & & & & & \\
\hline & 4 & Repeat & $21.05-30.06$ & 3 & 1 & & & & \\
\hline & 1 & 2 repeat & Mid-July & 1 & & & & & \\
\hline \multirow{3}{*}{ Fringilla coelebs } & 6 & 1 & $20.04-22.05$ & 6 & & & & & \\
\hline & $4-5$ & 2 & $22.05-21.06$ & 4 & & & & & \\
\hline & 2 & 3 & $28.06-29.07$ & 2 & & & & & \\
\hline \multirow{2}{*}{ Serinus serinus } & 2 & 1 & $2.05-12.06$ & 2 & & & & & \\
\hline & 2 & 2 & $23.06-10.08$ & 2 & & & & & \\
\hline Cyanistes caeruleus & 1 & 1 & $25.04-5.05$ & & & 1 & & & \\
\hline \multirow{2}{*}{ Linaria cannabina } & 1 & 1 & $29.04-30.05$ & & & & 1 & 1 & \\
\hline & 1 & 2 & $17.06-20.07$ & 2 & & & & & \\
\hline \multirow{2}{*}{ Columba palumbus } & 1 & 1 & late-April & 1 & & & & & \\
\hline & 1 & 2 & $4.07-8.08$ & 1 & & & & & \\
\hline Emberiza citrinella & 1 & 1 & $30.04-29.05$ & & & & & & 1 \\
\hline Jynx torquilla & 1 & 1 & $11.05-19.06$ & & & 1 & & & \\
\hline first clutch & \multicolumn{2}{|c|}{35 pairs/ha } & \multirow{3}{*}{ from 9.04 to 10.08} & 22 & 8 & 2 & 2 & 2 & 1 \\
\hline second clutch & \multicolumn{2}{|c|}{$19-20$ pairs $/ \mathrm{ha}$} & & 20 & & & & & \\
\hline third clutch & \multicolumn{2}{|c|}{2 pairs/ha } & & 2 & & & & & \\
\hline repeat clutches & \multicolumn{3}{|c|}{10} & 9 & 1 & & & & \\
\hline Total & \multicolumn{3}{|c|}{69} & 53 & 9 & 2 & 2 & 2 & 1 \\
\hline
\end{tabular}


Table 2. Height of nest sites in an old, traditionally managed orchard (metres).

\begin{tabular}{|c|c|c|c|c|c|}
\hline Species & Min. & Max. & Average & $\mathrm{SD}$ & $\mathrm{Me}$ \\
\hline Linaria cannabina & 1.1 & 2.5 & 1.7 & 0.64 & 1.7 \\
\hline Serinus serinus & 2.2 & 2.9 & 2.5 & 0.30 & 2.4 \\
\hline \multirow{6}{*}{ Turdus philomelos } & \multicolumn{5}{|c|}{ First clutch } \\
\hline & 1.4 & 2.9 & 2.2 & 0.53 & 2.4 \\
\hline & \multicolumn{5}{|c|}{ Second clutch } \\
\hline & 2.5 & 3.2 & 2.9 & 0.29 & 2.9 \\
\hline & \multicolumn{5}{|c|}{ All nests, including repeat clutches } \\
\hline & 1.4 & 3.2 & 2.4 & 0.49 & 2.5 \\
\hline \multirow{6}{*}{ Turdus merula } & \multicolumn{5}{|c|}{ First clutch } \\
\hline & 0.6 & 3.4 & 1.7 & 0.83 & 1.5 \\
\hline & \multicolumn{5}{|c|}{ Second clutch } \\
\hline & 2.1 & 3.4 & 2.6 & 0.68 & 2.4 \\
\hline & \multicolumn{5}{|c|}{ All nests, including repeat clutches } \\
\hline & 0.6 & 3.4 & 2.1 & 0.84 & 2.3 \\
\hline \multirow{6}{*}{ Turdus pilaris } & \multicolumn{5}{|c|}{ First clutch } \\
\hline & 1.2 & 2.8 & 2.2 & 0.53 & 2.4 \\
\hline & \multicolumn{5}{|c|}{ Second clutch } \\
\hline & 2.5 & 2.8 & 2.7 & 0.15 & 2.7 \\
\hline & \multicolumn{5}{|c|}{ All nests, including repeat clutches } \\
\hline & 1.2 & 2.9 & 2.4 & 0.44 & 2.4 \\
\hline \multirow{6}{*}{ Fringilla coelebs } & \multicolumn{5}{|c|}{ First clutch } \\
\hline & 1.8 & 3.0 & 2.3 & 0.44 & 2.5 \\
\hline & \multicolumn{5}{|c|}{ Second clutch } \\
\hline & 2.2 & 3.0 & 2.7 & 0.56 & 2.6 \\
\hline & \multicolumn{5}{|c|}{ All nests, including repeat clutches } \\
\hline & 1.8 & 3.6 & 2.5 & 0.52 & 2.4 \\
\hline
\end{tabular}

All these species sustained the greatest clutch losses at the beginning of the breeding season. Clutches laid after late May were more successful (Fig. 1). The second clutches of thrushes and chaffinch were laid in June. All the clutches of thrushes which were laid in nests at the base of a tree crown (type B) were unsuccessful. The thrush nests with successful clutches were built higher up (average $=2.6, \mathrm{SD}=0.23, \mathrm{Me}=2.5$ ) than those with unsuccessful clutches (average $=2.3$, $\mathrm{SD}=0.66, \mathrm{Me}=2.4)$. This relationship was not statistically significant $(\mathrm{U}=124.5, \mathrm{Z}=-1.38, \mathrm{p}=0.166)$. Chaffinch experienced a similar situation (average $=2.6$ vs. $2.4, \mathrm{SD}=0.55$ vs. $0.51, \mathrm{Me}=2.4$ vs. 2.35 ; test result $\mathrm{U}=13, \mathrm{Z}=-0.52, \mathrm{p}=0.607)$. In addition, territorial behaviour, mostly singing, was observed in the study area in the following species: skylark Alauda arvensis,

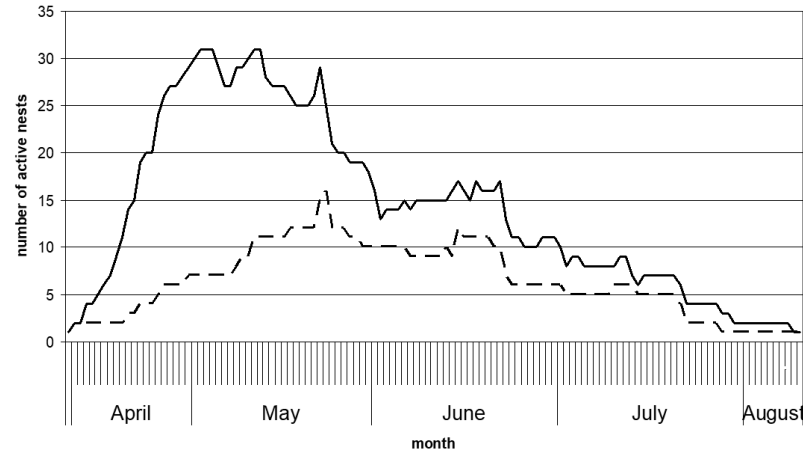

Fig. 1. Survival rate (number of nests/day) of nests with successful clutches (dashed line) vs. all nests (solid line).

starling Sturnus vulgaris, common whitethroat Sylvia communis, great tit Parus major, greenfinch Chloris chloris, tree sparrow Passer montanus and icterine warbler Hippolais icterina. They were not regarded as breeding birds because their nests were not found; their presence in this area will have been due to the fact that the orchard made up a part of their nesting territory.

\section{Discussion}

Both traditional and commercial orchards in Poland are plantations of trees, fruit bushes and berry crops, including hazelnut, raspberry and vine, which are densely planted if their total area is no smaller than 0.10 ha [definition: 16]. Poland has the largest area of orchards in Europe [17]: currently, they make up about $1.1 \%$ of the country's area. With a total area of 343265 ha, these plantations covered some $2.4 \%$ of the overall area given over to agriculture in 2013 [16]. Apple orchards accounted for $71 \%$ of the total number of cultivated trees. As regards age structure, apple trees aged 25 and more years made up the smallest percentage. Small orchards, no bigger than 1 ha, are dominant in Poland, but they are in decline: in 2012 some $67 \%$ of the total number of farms had such orchards, compared with around 77\% in 2007 [16]. These orchards supply $12.8 \%$ of all fruit crops, whereas plantations from $>1$ to nearly 5 ha in area supply ca $30 \%$. Orchards from 5.00 to 9.99 ha make up more than a quarter of the overall area of orchards in Poland, and orchards larger than 10 ha cover ca $31.5 \%$. However, the latter group supplied only about $3 \%$ of fruit crops (ca $1.5 \%$ in 2007). Comparison of the figures provided by the Polish Central Statistical Office in 2007 and 2012 reveals a tendency for fruit production to be concentrated on larger areas and a decrease in the number of small fruit plantations. This change has led to the elimination of old, traditional orchards from the agricultural landscape.

In intensively managed (commercial) orchards, the rule is frequent spraying and mowing the grass between trees rows as well as creating a herbicide setaside in a row [18-21]. According to data collected by 
E. Makosz in 1998, $18.46 \mathrm{~kg}$ of active substances in plant protection products per hectare were used in 78 "standard" unintegrated orchards in the Sandomierz and Grójec areas [22]; in subsequent years this amount did not decrease, as indicated by sales volumes [23]. In comparison, the consumption of active substances in plant protection products between 1991 and 1995 in orchards run on the basis of the integrated method in Western Europe was $20.3 \mathrm{~kg} \mathrm{ha}^{-1}$ in South Tyrol (Italy) and $17.3 \mathrm{~kg} \mathrm{ha}^{-1}$ in the Netherlands [22]. Such high doses of chemicals have an impact both on pest insects and on useful ones, that is, their predators [24]. Both herbicides and pesticides, despite their increasing toxicity class (toxicity decreases with increasing class number I-IV), decimate insect populations [25, 26]. Frequent mowing of herbaceous plants makes it difficult or even impossible for plants to seed and reduces the number of some insects [27]. Environments that are transformed in this way lose their self-regulation ability and thus require continuous human intervention.

Birds which nest in commercial orchards are affected by such limiting conditions as the lack of sufficient food [28] and difficulties in concealing their nests in a fruit tree monoculture of fruit trees due to the high level of crown transparency. Crown widths are limited to $60-80 \mathrm{~cm}$ (to $1.5-1.8 \mathrm{~m}$ in older types of commercial orchards) [29]. Moreover, more people enter the orchards at spraying times; during the birds' breeding season spraying is mostly done at night (in order to protect bees). There are also other factors like summer cuts (July-August), fertilisation, mowing of grass between tree rows and, in the case of cherry orchards, scaring birds away with the use of pyrotechnic agents and other methods. Changing the age structure of modern orchards is geared toward lowering it: this reduces trunk circumferences and obviously prevents the formation of tree holes during an orchard's lifetime.

The results from the traditional orchard near Mogielnica were compared with data collected in 2007 and again in 2008 in orchards in Brzumin (7.5 ha) and Czersk (9 ha) [30]. The author of that work carried out an inventory of birds in a commercial orchard using a similar nest-searching method. Approximately 70\% of these orchards contained trees aged 6-10 years, the remainder were older trees aged ca 19 years. In 2007-2008, a total of 10 species of nesting birds were found over an area of 16.5 ha. Six species were common to both Brzumin and Czersk (blackbird, fieldfare, song thrush, serin, common linnet, chaffinch), three were found only in the Brzumin orchard and one in Czersk [30]. Although magpie Pica pica is treated as a nesting species, its clutches are regarded as random, not specifically associated with the orchard as a habitat. Both types of orchard (traditional vs. commercial) were inhabited by the same number of species. There were no hole nesters in the Brzumin and Czersk orchards, as could be inferred from their age and the lack of tree holes [30]. The absence of yellowhammer in commercial orchards should be treated as an omission on the

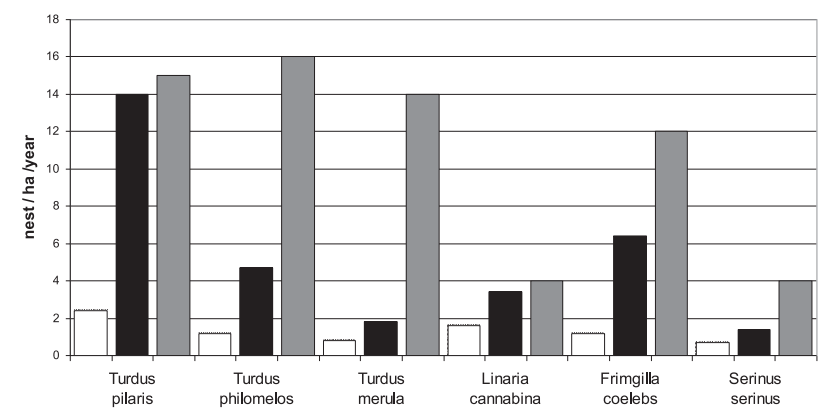

Fig. 2. Number of nests built by the most numerous species in the three types of orchards: hatched - young, commercial orchard, black - older, commercial orchard, grey - traditional orchard (Mogielnica).

part of the researcher because of the large area of the survey plot. There were twice as many nests built in a traditional orchard than in a commercial orchard and nine times more than in a young commercial orchard. The small difference between the number of nests in an old, traditional orchard and an old, commercial orchard is surprising. This suggests that the age of trees is a limiting factor for some species to build nests in an orchard. In all three types of orchards, fieldfare built the most nests (Fig. 2). In an old, traditional orchard, the three thrush species were numerically dominant, whereas fieldfare and chaffinch dominated the old, commercial orchard. The larger number of thrush nests in the old, traditional orchard is due to the larger tree crowns, which effectively conceal big nests. It is this feature (patulous, large tree crown) that appears to determine the greater number of thrushes in traditional orchards. Blackbird, a woodland shade species [31], built its nests at the lowest height in the traditional orchard (Table 2) and only occasionally in the well-illuminated, narrow crowns of commercial trees (Fig. 2). As the season progressed, it built its nests higher up, a fact confirmed by other researchers [32-35].

Because of the lack of up-to-date nationwide data on the success of the focal species' clutches in orchards, a study carried out near Poznań in the early 1980s was used in order to make comparisons [36]. The effectiveness of clutches near Mogielnica was similar to that given in [36]: it was $26.9 \%$ for birds that build open nests, even though many low-toxicity products but of proven lethality were applied in the 1980s [37]. Chaffinch was an exception, as its breeding success was low (5 to $25 \%$ ) in an old, commercial orchard, in contrast to the traditional orchard near Mogielnica, where this success was $67 \%$. This indicates that the limiting factor here was something other than the type of tree crown. This is confirmed by the highest breeding success of blackbird, common linnet and chaffinch among the species assessed in a young, commercial orchard (Fig. 3). The low breeding success of blackbird in an old, traditional orchard was distinctive (Fig. 3), even though it built many nests (Fig. 2). This may have been due to the low height of 


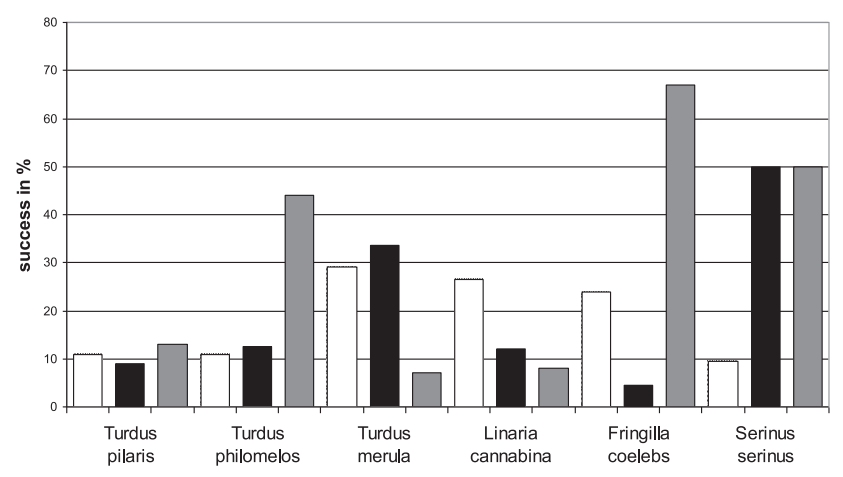

Fig. 3. Percentage breeding success in the three types of orchards: hatched - young, commercial orchard, black - older, commercial orchard, grey - traditional orchard (Mogielnica).

nests (average $=2.1 \mathrm{~m}, \mathrm{SD}=0.84, \mathrm{Me}=2.3$ ); this was the lowest of all the thrush species, and the type of nest site (type B), which was not well hidden from predators (Table 1). Blackbirds in Poland build their nests lower down than song thrushes and the breeding success of the former species is lower than that of the latter [38].

Predation is seen as the main cause of nest destruction [38] and affects mainly nests at low heights [34]. Blackbirds often built their nests at the base of a tree crown, in a recess or in the fork of the main trunk, probably because of the slower growth of foliage early in the nesting season and difficulties in finding a wellconcealed site. This statement can be justified by the fact that blackbird is a species that prefers low bushes [39]. These results are confirmed by an analysis of nest cards [38]. Although they built fewer nests, blackbird, common linnet and chaffinch achieved greater breeding success in a young commercial orchard (Figs 2, 3). Nests for second and repeat clutches were built in tree crowns (Table 1). Birds suffered greater losses in first clutches than in second and repeat ones, suggesting that the growth of foliage, enabling a nest to be more effectively concealed, reduced losses. Research performed in Szczecin parks confirms this, where the first nests were built in coniferous trees; as the foliage became more luxuriant, blackbirds tended to prefer chose deciduous trees [35].

The high density of birds nesting in orchards in comparison to other habitats is surprising. In commercial orchards, this figure was 7-31 nests/ha [30]. In the traditional orchard near Mogielnica, this density was even higher, at around 68 nests/ha; if we include unfinished nests of unidentified species it rises to as many as 82 nests/ha. It is this parameter that distinguishes traditional orchards from commercial ones. The density parameter (number of nests/ha) is not used in typical research, so it can be compared only indirectly. However, it does provide a picture of the uniqueness and specific nature of this type of agricultural landscape. In an orchard in Romania, where the age of trees varied from 1 to 80 years, 242.5 pairs/10 ha were found (as cited in [36], Korodi Gal). If we calculated the density per hectare in the traditional orchard near Mogielnica for 10 ha, 350 pairs would have successful clutches (see Table 1) - which exceeds the highest densities of birds recorded in Poland's rich marshy meadows (for example 215 pairs/10 ha [40] and parks (for example 294 pairs/10 ha [41]). The high density in the habitats compared was determined by the proportion of hole nesters: $54.9 \%$ of the birds in the Romanian orchard, $45-60 \%$ in marshy meadows and approximately $60 \%$ in parks. In commercial orchards, which are used for 15-20 years on average, (nest) hole formation is not possible because of the small circumferences of trunks. Hence old, traditional orchards have plenty of potential nest holes, whereas commercial orchards have none. Apart from clutches of blue tit Cyanistes caeruleus and wryneck Jynx torquilla during the breeding season, tree sparrow Passer montanus (pair nesting beyond the orchard), starling Sturnus vulgaris (a bird carrying food, nesting beyond the orchard), and great tit Parus major (2 pairs nesting beyond the orchard) were sighted in or close to the orchard. The species composition and number of hole nesters (including species sighted during the season but without nests) were identical to those in the orchard near Poznań [42], and these were species nesting in nest boxes. No hole nesters were found in the Brzumin and Czersk orchards [30]. This indicates that the assemblage of hole-nesting birds is characteristic of old, traditional orchards with holes or of younger, commercial orchards, so long as nest boxes have been erected. This is confirmed by research performed in orchards near Poznań. Out of a total of 174 nest boxes, starlings nested in 65 , tree sparrow in 23 , great tit in three and blue tit in two of them [43].

Being monocultures, orchards can boast only a small number of nesting species, which is several times smaller than in the previously mentioned rich habitats like marshy meadows or city parks. If the list of species nesting in orchards is supplemented by, for example, jay Garrulus glandarius, magpie Pica pica, mistle thrush Turdus viscivorus, black redstart Phoenicurus ochruros, white wagtail Motacilla alba, wheatear Oenanthe oenanthe, common redstart Phoenicurus phoenicurus and mallard Anas platyrhynchos, one becomes aware that the survey area probably comprised other habitats besides orchards, such as ponds, Prunus spinosa and other shrubs, old Pyrus pyraster on baulks, coniferous trees near buildings in rural areas, abandoned buildings with a natural succession of trees, or bushes and herbaceous plants, or that nest boxes were deployed in that orchard [i.a., 36, 43-45]. Using extensive (relative) methods of counting birds for determining the species composition of nesting birds in an orchard is inappropriate. Abundance recorded on transects or with the use of the PFS (progressive frequential sampling) method in the breeding season may be the result of including birds that do not nest in the area but visit it to search for food, or species which are present because 
their habitats lie close to orchards [i.a., 46-48]. Therefore, the assessment of species diversity in orchards should be preceded by a thorough analysis of the area's habitat structure and the presence of atypical habitats in the research area. Such habitats should be excluded when assessing the species composition of birds that nest in orchards. The impoverished composition of bird life in orchards is the upshot of their being monocultures, the lack of any undergrowth and the scarce ground layer, which in addition is often mown. In old orchards, which fructify late, the planting of gooseberries or currants in rows used to be characteristic. In those days, the nesting bird assemblage would comprise species associated with bushes, for example, greenfinch Chloris chloris, common whitethroat Sylvia communis, common linnet Linaria cannabina, lesser whitethroat Sylvia curruca and also yellowhammer, red-backed shrike Lanius collurio, goldfinch Carduelis carduelis and serin (S. Chmielewski, own data).

\section{Conclusions}

The advantage of traditional orchards over commercial orchards as regards diversity is a frequent topic of discussion [i.a., 3, 5, 47, 48]. Even though pesticides were not used in the old, traditionally managed orchard near Mogielnica, its composition of bird species was almost the same as in the commercial orchards near Czersk and Brzumin. This indicates that the present-day use of chemicals and the intensity of farm work do not limit the composition of bird species. In all probability, this composition is fixed and characteristic of orchards near Grójec and Warka. Three thrushes were dominant in the breeding assemblage, which was generally poor in species. Their density, assessed on the basis of nests found, ranged from 6 to 8 pairs/ha. In terms of species structure, the old, traditional orchard was dominated by fieldfare, while chaffinch came second and song thrush third. What distinguishes old orchards from other habitats is the very high density of birds and the simplified species composition. The lack of tree holes in commercial orchards prevents these from being populated by hole nesters. It also precludes the effective limiting role which this group of birds could have on pest insects in orchards. Studies of hole nesters and birds nesting in orchards may well become important in the near future, owing to the impact they may have on the use of organic methods of fruit production. Many studies have highlighted the part played in orchards by great tit and other hole nesters in reducing the number of caterpillars of winter moth Operophtera brumata or codling moth Cydia pomonella, and also the various developmental forms of psyllids Cacopsylla spp., which subsequently leads to a greater fruit harvest [49, 50]. Therefore, research into monoculture orchards should continue in order to develop a sustainable model for their management.

\section{Conflict of Interest}

The authors declare no conflict of interest.

\section{References}

1. MIKA A. Secrets of fruit trees. PWRiL, Warsaw. 2016 [In Polish].

2. CIARKOWSKA K., MAZUREK R., NIEMYSKAŁUKASZUK J. Influence of pesticides on biolobical activity of soils in apple orchards on the basis of micromophological studiem. Acta Agraris et Silvestria ser. Agraria 45, 37, 2005 [In Polish].

3. GAJDEK A. About old orchards in the landscape. Aura 12, 24, 2013 [In Polish].

4. DAVIES G.M. Corehead Orchard Tree Establishment and Grazing Damage Survey. Report to the Borders Forest Trust. 2014.

5. BAILEY D., SCHMIDT-ENTLING M.H., EBERHART P., HERRMANN J.D., HOFER G., KORMANN U., HERZOG F. Effects of habitat amount and isolation on biodiversity in fragmented traditional orchards. Journal of Applied Ecology. 47, 1003, 2010.

6. BURROUGH A.E., OINES C.M., ORAM S.P., ROBERTSON H.J. Traditional orchard project in England - the creation of an inventory to support the UK Habitat Action Plan. Natura England Commissioned Reports. no. 77, 2010.

7. TRYJANOWSKI P., KUŹNIAK S., KUJAWA K., JERZAK L. Ecology of farmland birds. Bogucki Wydawnictwo Naukowe, Poznań. 2009 [In Polish].

8. MÜHLNER S., KORMANN U., SCHMIDT-ENTLING M., HERZOG F., BAILEY D. Structural versus functional habitat connectivity measures to explain bird diversity in fragmented orchards. Journal of landscape ecology. 3 (1), $52,2010$.

9. MYCZKO Ł., ROSIN Z. M., FLISZKIEWICZ M., TRYJANOWSKI P. Birds living in orchards - the past, the present and the future: an integrative view from Poland. Ber. Inst. Landschafts - Pflanzenökologie Univ. Hohenheim Beiheft, 26, 49, 2011.

10. HORAK J., PELTANOVA A., PODAVKOVA A., SAFAROVA L., BOGUSCH P., ROMPORTL D., ZASADIL P. Biodiversity responses to land use in traditional fruit orchards of a rural agricultural landscape. Agriculture, ecosystems \& environment. 178, 71, 2013.

11. ŠPULEROVÁ J., PISCOVÁ V., GERHÁTOVÁ K., BAČA A., KALIVODA H., KANKA, R. Orchards as traces of traditional agricultural landscape in Slovakia. Agriculture, Ecosystems and Environment. 199, 67, 2015.

12. MENG J., LI L., LIU H., LI Y., LI C., WU G., YU X., GUO L., CHENG D., MUMINOV M.A., LIANG X., JIANG G. Biodiversity management of organic orchard enhances both ecological and economic profitability. PeerJ 4:e2137 https://doi.org/10.7717/peerj.2137, 2016.

13. GOTZMAN J., JABŁOŃSKI B. The nests of our birds. PZWS, Warsaw. 1972 [In Polish].

14. HUDEC K. Eds. Fauna ČSSR, Volume 23-24, Birds Aves, III/1-2. Akademia, Praha. 1983 [In Czech].

15. TOMIAŁOJĆ L. The combined version of the Mapping Method. Mikusek R., Stawarczyk T. Eds., Ornithologist Guide. Wydawnictwo Fundacja Wspierania Inicjatyw Ekologicznych, Kraków. 2014 [In Polish]. 
16. ŁĄCZYŃSKI A., NISZCZOTA S., DUBIENECKA H., DZIUBIŃSKI K., KUPIDURA A., MILEWSKI T., MIZIOŁEK D., RAFA W., RUSZKOWSKA Z., SIESTRZEWITKOWSKA A. Land use and sown area in 2013. Central Statistical Office. 2014 [In Polish].

17. PIZŁO W. Prospects for the development of apple farms in Poland and in the EU countries. Scientific Journal Warsaw University of Life Sciences - SGGW. Problems of World Agriculture, 14 (2), 185, 2014 [In Polish].

18. SIMON S., BOUVIER J.C., DEBRAS J.F., SAUPHANOR B. Biodiversity and pest management in orchard systems. A review. Agronomy for Sustainable Development, 30, 139, 2010.

19. ATUCHA A., MERWIN I.A., BROWN M.G. Long-term effects of four groundcover management systems in an apple orchard. Hort Science. 46, (8), 1176, 2011.

20. BRETH D., TEE E., DONAHUE D., WALLIS A. Managing Apple Orchard Weeds in the Fall. New York Fruit Quarterly. 24, (4), 9, 2016.

21. LICZNAR-MAŁANCZUK M., SYGUTOWSKA I. The weed composition in an orchard as a result of long-term foliar herbicide application. Acta Agrobotanica. 69, 1685, 2016.

22. KLIMEK G. Polish apple. Hasło ogrodnicze, 5, 3, 2000 [In Polish].

23. JARECKI W., BOBRECKA-JAMRO D. The consumption of basic production means in Polish agriculture in respect to sustainable development of agriculture and rural areas. Ecological Engineering, 34, 121, 2013 [In Polish].

24. http://nhsjs.com/2015/effects-of-chemical-pesticides-onbeneficial-and-harmful-insect-populations-on-four-farmsin-central-massachusetts/ (20.11.2017)

25. BOLIGŁOWA E. Environmental aspects of the use of plant protection chemicals. Filipek-Mazur B. Eds., Environmental aspects of the application of fertilizers and plant protection products in agriculture. WUR, Krakow. 2011 [In Polish].

26. HLADIK M.L., VANDEVER M., SMALLING K.L. Exposure of native bees foraging in an agricultural landscape to current-use pesticides. Science of the Total Environment, 542, 469, 2016

27. MARLIAC G., SIMON S., MAZZIA C., PENVERN S., LESCOURRET F., CAPOWIEZ Y. Increased grass cover height in the alleys of apple orchards does not promote Cydia pomonella biocontrol. BioControl, 60, 805, 2015. https://doi.org/10.1007/s10526-015-9687-y

28. ISENRING R. Pesticides and the loss of biodiversity. Pesticide Action Network Europe, London. 2010.

29. LEGAŃSKA Z. Eds. The apple trees. Publisher Hortpress, Warszawa. 2012 [In Polish].

30. GRĘDZIŃSKI P. Breeding ecology of the birds in intensive farmer orchards. Engineering work, SGGW, Warsaw. 2009 [In Polish].

31. DYRCZ A. Comparative studies on the avifauna of woods and parks. Acta Ornithologica, 7 (11), 337, 1963 [In Polish].

32. DYRCZ A. The ecology of the Song Thrush and Blackbird during the breeding season in an area of their joint occurrence. Ekologia Polska Seria A, 17, 735, 1969.

33. SCHNACK S. The breeding biology and nestling diet of the Blackbird Turdus merula L. and the Song Thrush Turdus philomelos C. L. Brehm in Vienna and in an adjacent wood. Acta Ornithologica, 26 (2), 85, 1991.

34. LUDVIG E., VANICSEK L., TÖRÖK J., CSÖRGÖ T. The effect of nest-height on the seasonal pattern of breeding success in blackbirds Turdus merula. Ardea 83, 411, 1995.
35. WYSOCKI D. Nest site selection in the urban population of Blackbirds Turdus merula of Szczecin (NW Poland). Acta Ornithologica, 40 (1), 61, 2005.

36. KWIATKOWSKA G. Birds building open nests in multihectare orchards. Yearbooks of the Academy of Agriculture in Poznan 208, Applied Ornithology, 14, 3, 1989 [In Polish].

37. MROCZKIEWICZ D. The insecticide influence on Birds nesting in Przybroda experimental orchard. Yearbooks of the Academy of Agriculture in Poznan 41, Applied Ornithology, 12 (3), 149, 1968 [In Polish].

38. WESOLOWSKI T., CZAPULAK A. Breeding biology of blackbird and song thrush in Poland - a preliminary analysis of nest cards. Notatki Ornitologiczne, 27 (1-2), 31, 1986 [In Polish].

39. MIKULA P., HROMADA M., ALBRECHT T., TRYJANOWSKI P. Nest site selection and breeding success in three Turdus thrush species coexisting in an urban environment. Acta Ornithologica, 49 (1), 83, 2014.

40. TOMIAŁOJĆ L., DYRCZ A. Nature conservation in large river valleys of Poland: an ornithological outlook. Tomiałojć L Eds. Nature and environment conservation in the lowland river valleys of Poland. IOP PAN, Krakow, 13, 1993 [In Polish].

41. TOMIAŁOJĆ L. Changes in breeding bird communities of two urban parks in Wrocław cross 40 years (1970-2010): before and after colonization by important predators. Ornis Polonica, 52 (1), 1, 2011.

42. LEMPASZAK U. Ecology of hole Birds nesting in the breeding boxes in the orchards. Part 1. Breeding. Yearbooks of the Academy of Agriculture in Poznan 208, Applied Ornithology, 14, 33, 1989 [In Polish].

43. GRACZYK R., MROCZKIEWICZ D. The influence of practical conservation upon number and distribution of Birds in the experimental orchard at Przybroda (Province of Poznań). Prace Komisji Nauk Rolniczych i Leśnych. PTPN, 23 (1), 65, 1967 [In Polish].

44. CHMIELEWSKI S. Breeding avifauna of orchards and adjacent habitats At Wysoczyzna Rawska (the Rawska Hills). Ornis Polonica, 57 (1), 29, 2016.

45. ROSIN Z. M., SKÓRKA P., PÄRT T., ŻMIHORSKI M., EKNER-GRZYB A., KWIECIŃSKI Z., TRYJANOWSKI P. Villages and their old farmsteads are hot-spots of bird diversity in agricultural landscapes. Journal of Applied Ecology, 53, 1363, 2016.

46. WIACCEK J., POLAK M. Bird community breeding in apple orchards of Central Poland in relation to some habitat and management features. Polish Journal of Environmental Studies, 17 (6), 951, 2008.

47. KATAYAMA N. Bird diversity and abundance in organic and conventional apple orchards in northern Japan. Scientific Reports 6, 34210; doi: 10.1038/srep34210, 2016.

48. BOUAM I., BACHIR A. S. KATAYAMA, N. Variation in bird assemblages along an agricultural intensification gradient: a case study of olive orchards in north-eastern Algeria. Ornithological Science, 16 (2), 147, 2017.

49. MOLS C.M., VISSER M.E. Great tits can reduce caterpillar damage in apple orchards. Journal of Applied Ecology, 39 (6), 888, 2002.

50. BOUVIER J.C., RICCI B., AGERBERG J., LAVIGNE C. Apple orchard pest control strategies affect bird communities in southeastern France. Environmental Toxicology and Chemistry,30 (1), 212, 2011. 